4. Roach RC, Bärtsch P, Oelz O, Hackett PH. The Lake Louise acute mountain sickness scoring system. In: Sutton JR, Houston CS, Coates G, eds. Hypoxia and Molecular Medicine. Burlington, VT: Queen City Printers; 1993:272-274.

5. Wu TY, Ding SQ, Zhang SL, et al. Altitude illness in Qinghai-Tibet railroad passengers. High Alt Med Biol. 2010;11:189-198.

\section{An Unprovoked Attack by a Blue Shark Prionace glauca (Chondrichthyes: Carcharhinidae) on a Spear Fisherman in Terceira Island, Azores, Northeast Atlantic}

\section{To the Editor:}

The blue shark, Prionace glauca (Linnaeus, 1758) (Figure 1A), is a large predatory oceanic-epipelagic species with worldwide distribution that is usually harmless to humans. However, its inquisitive behavior when facing divers in open waters and a moderately powerful set of jaws and teeth can inflict severe injuries (Figure 1B), reasons for this shark to be regarded with caution in some shark-human interaction scenarios. There are at least 13 recorded unprovoked attacks imputed to this species to date (eg, http://www.flmnh. ufl.edu/fish/sharks/statistics/species3.htm).

On July 24, 2013, near a shallow water rocky reef approximately $50 \mathrm{~m}$ from the coastline, a 48-year-old spear fisherman was surprised by a blue shark that bit his

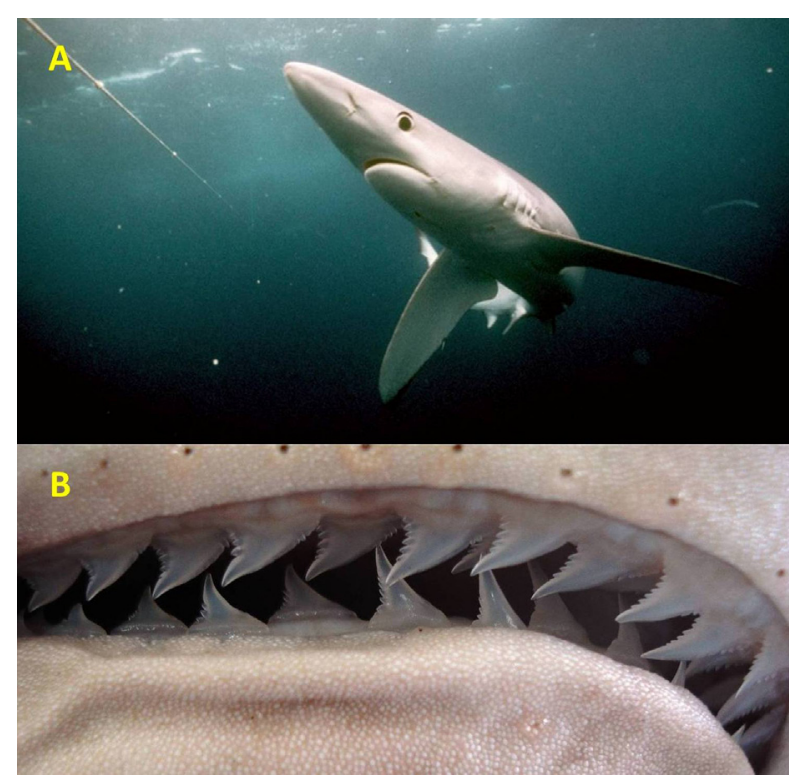

Figure 1. An adult blue shark Prionace glauca (Linnaeus, 1758), showing (A) its main body diagnostic features, and (B) the right anterolateral view of the jaws of a subadult specimen (B). Photographs by H. Wes Pratt (A) and Otto B. F. Gadig (B). right flipper. The incident occurred on the South coast of Terceira Island, Azores, Portugal, Northeast Atlantic, where a shark attack or conflict is a very rare phenomenon, having only 3 minor incidents previously recorded. ${ }^{1,2}$ The victim, an experienced professional marine biologist and diver from the region, knows the Azorean ichthyofauna, particularly the Chondrichthyans, and easily identified the shark species based on its slender body, dark blue color, and elongated snout and fins.

Late afternoon the spear fisherman entered the water and swam away from the adjacent fishing port, now converted into a leisure summer area, toward the tip of the adjacent rocky reef. There, he saw a school of Atlantic Bonito, Sarda sarda (Bloch, 1793) and immediately dove to place himself in a position suitable to target one of the fish swimming in front of him. As he descended to a depth of approximately $10 \mathrm{~m}$, he felt his right foot being pushed and turned his head to see an approximately $2.1 \mathrm{~m}$ total length blue shark biting his flipper. The teeth marks left in the upper flipper surface (Figure 2) indicate, at least, 2 almost simultaneous incomplete bites by the shark lateral jaws, possibly trying to grab and then remove a piece, as is usually observed in the bite kinematics of large Carcharhinidae sharks. ${ }^{3}$ At the same time, he reported that at least 5 more similar-size blue sharks were close by, and he was able to chase the first specimen away simply by touching it with his left leg. The sharks disappeared, and the victim continued to fish in that same area with no further sightings.

Shark diving in the Azores is a commercially increasing summer tourist product that started in 2011 and is attracting a considerable number of tourists mainly to dive with this species and the less common shortfin mako shark Isurus oxyrinchus (Rafinesque, 1810; eg,

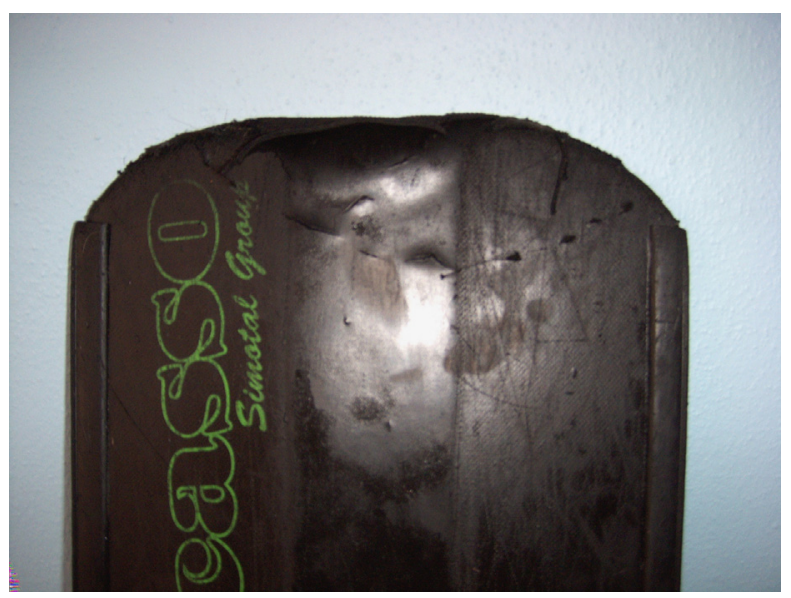

Figure 2. The victim's flipper showing the tooth marks made by the attack of a $2.1 \mathrm{~m}$ total length blue shark, Terceira Island, Azores, Portugal. Photograph by João Pedro Barreiros. 
http://www.cwazores.com/sharkdiving.aspx). These offshore, mainly pelagic species do have coastal habits when in close proximity to oceanic islands, as happens to be the Azores. Moreover, they are attracted by tourist operators with feeding stimuli and may be already in the process of associating these stimuli with humans, namely, divers. Contrary to well-known coastal sites where this practice is common and local sharks seem to have residential habits while becoming conditioned by specific diving sites, Azorean targeted species roam vast areas and far away from the open water zones where they are mainly attracted. In spite of the fact that some of the most dangerous species are seldom seen in the Azores, ${ }^{1,2}$ we believe that this practice of proximity and feeding stimuli to open water nonresident sharks is potentially dangerous and may well lead to more, possibly very serious, accidents in Azorean waters in the future.

In our opinion, close proximity of large predatory vertebrates to humans may well lead to accidents that sometimes may even be lethal. Apex predators, when accustomed to being enticed with food by humans, either for tourist purposes or from simple curiosity, are known to increase attacks. ${ }^{4}$ Changes in shark behavior due to touristic activities such as "shark diving" were also documented by Hammerschlag et al. ${ }^{5}$ We do think that care and common sense must surely prevail in these cases, while dealing with situations than can easily get out of control and lead to serious risks and overwhelming panic situations, which, if nothing else, will inevitably affect tourist activities as a whole.

\section{Acknowledgments}

The authors wish to thank our colleague and victim of this incident who kindly and accurately reported it to us. Thanks also to Dr. H. Wes Pratt (Mote Marine Laboratory's Tropical Research Laboratory, Summerland Key, Florida) for allowing us to use his awesome blue shark underwater photo, and to the anonymous reviewers of the manuscript.

João Pedro Barreiros

Azorean Biodiversity Group

Platform for Enhancing Ecological Research \&

Sustainability

Universidade dos Açores

Departamento de Ciências Agrárias

Angra do Heroísmo, Portugal

Otto B.F. Gadig

Elasmobranch Research Laboratory

São Paulo State University

São Vicente, Brazil

Vidal Haddad Jr.

Botucatu Medical School

São Paulo State University

São Paulo, Brazil

\section{References}

1. Barreiros JP, Gadig OBF. Sharks and Rays From the Azores, an Illustrated Catalogue. Angra do Heroísmo: Instituto Açoriano de Cultura; 2011:123-124.

2. Haddad V Jr, Barreiros JP. Dangerous and Venomous Marine Animals of Azores. Praia da Vitória: BLU Edições; 2007:47.

3. Moss SA. Feeding mechanism in sharks. Am Zool. 1977; 17:355-364.

4. Neto MFC, Garrone Neto D, Haddad V Jr. Attacks by jaguars (Panthera onca) on humans in Central Brazil: report of three cases, with observation of a death. Wilderness Environ Med. 2011;22:130-135.

5. Hammerschlag N, Gallagher AJ, Wester J, Luo J, Ault JS. Don't bite the hand that feeds: assessing ecological impacts of provisioning ecotourism on an apex marine predator. Funct Ecol. 2012;26:567-576. 